\title{
ESTIMASI PRODUKSI SUMBER DAYA ALAM (PRODUK TAMBANG) DAN TINGKAT KELULUSAN SEKOLAH SERTA JUMLAH TENAGA KERJA TERHADAP PERTUMBUHAN EKONOMI DI INDONESIA (STUDI KASUS PROPINSI)
}

\author{
Frances Roi Seston Tampubolon \\ Program Studi Manajemen Informasi, Fakultas Komputer \\ Universitas Mohammad Husni Thamrin \\ Jakarta, Indonesia \\ franjk@hotmaill.com
}

\begin{abstract}
This research is about estimating the influence of natural resources and school graduation rates and the number of workers on economic growth in Indonesia. The model used is multiple linear regression with one dependent variable and four independent variables. The method used is the OLS (Ordinary Least Square) method, where the estimated parameters of the models are verified by statistical tests. The variables used in this study include the length of time for
\end{abstract}

\section{PENDAHULUAN}

Sumber daya manusia dari suatu bangsa merupakan faktor paling menentukan karakter dan kecepatan pembangunan sosial ekonomi suatu bangsa bersangkutan (Todaro, 1997). Konsep bahwa investasi di dalam human kapital khususnya dalam hal investasi di pendidikan secara langsung memberikan kontribusi terhadap pertumbuhan ekonomi dengan meningkatkan keahlian atau kapasitas produksi dari tenaga kerja (Schultz, 1961 dan Denison, 1962). Seperti yang diungkapkan oleh Amich Alhumami bahwa betapa kuatnya hubungan antara pendidikan dan pembangunan ekonomi. Pendidikan sebagai medium bagi proses transmisi teknologi dianggap sebagai pendorong pembagunan ekonomi. Ada beberapa catatan yang perlu diperhatikan saat kita berbicara tentang hubungan antara pendidikan dan pembangunan ekonomi. Kita harus melihat pendidikan sebagai suatu investasi pada modal manusia (human capital investment). Selanjutnya kita akan melihat apakah ada dampak positif dari investasi efektif terhadap kesejahteraan masyarakat. Konsep mengenai investasi di dalam human resources adalah seperti yang dinyatakan oleh Adam

Smith yang menekankan pada pentingya investasi di skill pada sumber daya manusia. Pada awal dasawarsa 1960-an studi ekonomi yang membahas hubungan pendidikan dengan pertumbuhan ekonomi sangat mempengaruhi keputusan di negara-negara berkembang. Percepatan dan pemerataan penyediaan pendidikan formal secara kuantitatif sebagai kunci kesuksesan pembangunan ekonomi. ${ }^{1}$ Baru baru ini Bank Dunia telah menekankan peranan pengembangan sumber daya manusia khususnya di dalam pendidikan. Kecenderungan ini yang mendorong meningkatnya permintaan akan pendidikan lebih tinggi school graduation, the number of labor (labor), mining products, and PMTDB (formation of gross domestic fixed capital). The results of data processing show that natural resources (mining products) have a positive contribution to Indonesia's economic growth. From the last analysis that the school graduation rate also has a positive relationship to economic growth.

KeyWords : School Graduation, Natural Resources, Labor

(Todaro, 1997). Pendidikan memberi kontribusi signifikan pada pertumbuhan ekonomi melalui dua cara. Yang pertama adalah pendidikan menciptakan pengetahuan baru yang membawa pengaruh terhadap proses produksi. Pendekatan ini lazim disebut schumpeterian growth yang mengandaikan pertumbuhan ekonomi itu didorong akumulasi modal manusia. Modal manusia yang diperankan kaum profesional, para ahli teknisi, dan pekerja merupakan penggerak utama kemajuan ekonomi. Kedua pendidikan menjadi medium bagi proses difusi dan transmisi pengetahuan, teknologi dan informasi yang dapat mengubah cara berpikir, cara bertindak dan kultur bekerja. ${ }^{2}$ Investasi di bidang pendidikan secara langsung maupun tidak langsung dapat memberikan manfaat terhadap individu maupun secara sosial. Hal yang paling kelihatan manfaat secara langsung adalah bahwa pekerja yang berpendidikan menerima pendapatan yang lebih tinggi daripada mereka yang tidak memiliki pendidikan. Pendapatan yang diperoleh dapat dilihat dari 2 cara. Yang pertama dengan melihat karir dari beberapa pekerja selama masa periode tertentu dan melihat bagaimana perubahan pendapatan yang mereka dapatkan. Yang kedua adalah dengan melihat sampel dari pekerja dengan usia yang berbeda pada satu satuan waktu. Di dalam penelitian ini saya mencoba melihat:

1. Bagaimana pengaruh dari sumber daya alam khususnya produk tambang dan tingkat kelulusan sekolah terhadap pertumbuhan ekonomi propinsi di Indonesia dari tahun 2003 hingga 2005?

2. Apakah pengaruh tingkat pendidikan lebih besar dari pada sumber daya alam terhadap pertumbuhan ekonomi propinsi?

Untuk melihat besarnya pengaruh tersebut saya mencoba menggunakan waktu lamanya bersekolah (mean year of schooling) sebagai variabel dari tingkat pendidikan. 
Selanjutnya dengan membandingkan dari sisi suplai sumber daya alam, apakah pemanfaatan sumber daya alam memberikan dampak yang lebih besar apabila dibandingkan dengan sumber daya manusia khususnya di bidang pendidikan. Seperti yang kita ketahui bahwa ada beberapa daerah yang memiliki sumber daya alam yang sangat besar namun tidak didukung oleh tingkat keahlian atau skil untuk mengelola produk sumber daya alam tersebut. Sementara ada juga di beberapa daerah yang kurang memiliki sumber daya alam yang besar di daerahnya namun memiliki sumber daya manusia yang cukup baik. Hal inilah yang menjadi bahan pertimbangan saya di dalam penelitian ini untuk melihat seberapa besar pengaruh dari masing-masing sumber daya tersebut terhadap pertumbuhan ekonomi propinsi. Untuk melihat keterkaitan antara hubungan kedua sisi suplai tersebut selanjutnya akan diperoleh dari pengolahan data di dalam penelitian ini.

\section{Studi Empiris}

Model Solow difokuskan pada 4 variabel yaitu: output (Y), kapital (K), tenaga kerja (L), dan ilmu pengetahuan atau tenaga kerja efektif (A). Pada waktu apapun mempunyai sejumlah tertentu kapital, tenaga kerja, dan teknologi, dan semuanya ini dikombinasikan untuk menghasilkan output ${ }^{2}$. Fungsi produksi tersebut merupakan fungsi dari kapital (K), tenaga kerja (L), dan teknologi (A). Variabel tenaga kerja (L) dan teknologi (A) merupakan efektif labor yang selanjutnya akan menjadi (AL). Sehingga fungsi produksinya berbentuk $\mathrm{Y}(\mathrm{t})=$ $\mathrm{F}\{\mathrm{K}(\mathrm{t}), \mathrm{A}(\mathrm{t}) \mathrm{L}(\mathrm{t})\}$.

a. Studi empiris yang telah dibuat sebelumnya merupakan aplikasi model dari Cobb- Douglas. Sebuah fungsi produksi yang dimodelkan sebagai fungsi tenaga kerja (labor), modal (physical capital), dan human capital (HC). Fungsi produksi tersebut dinyatakan sebagai (Emadzadeh, 2000).

b. Judson (1998), melakukan regressi physical capital dan human capital terhadap pertumbuhan PDB dengan menggunakan panel data mencakup 138 negara pada periode 1970-1990. Pada regressi ini, human capital stock diukur dari education- spending. Hasil estimasi adalah koefisien yang positif (10.83) yang merupakan efek pendidikan pada pertumbuhan PDB. Negara-negara yang mengalokasikan (investasi pendidikan) secara tidak efisien memperoleh manfaat yang kecil bila dibandingkan negara-negara yang mengalokasikan secara efisien.

c. Beddies (1999) melakukan studi hubungan pertumbuhan PDB dengan pertumbuhan labour (augmented capital proxy) untuk negara Gambia pada tahun 1964-1998. Hasil regressi mengindikasikan bahwa human capital accumulation mempunyai pengaruh utama pada pertumbuhan ekonomi. Dari hasil tersebut, otoritas kebijakan perlu meningkatkan capital accumulation melalui peningkatan tingkat dan kualitas pendidikan

\section{II.METODE PENELITIAN}

Data yang digunakan untuk mengetahui pengaruh pendidikan tinggi terhadap tingkat pertumbuhan domestik bruto (PDB) adalah sebagian besar didapatkan dari BPS (Badan Pusat Statistik), SUSENAS pada tahun
2003-2005 dan bersifat gabungan dari data seksi silang atau (cross section) dan runtun waktu (time series) yaitu data panel. Model yang diajukan adalah adalah regresi linier berganda dengan satu variabel terikat dan tiga variabel bebas. Metoda yang digunakan adalah Ordinary Least Square (OLS) yang taksiran parameter-parameter modelnya diverifikasi dengan uji statistik. Beberapa uji dilakukan terhadap model diantaranya uji multikolinearitas, uji heteroskedastisitas, uji autokorelasi, uji stasioner dan uji normalitas. Pengolahan data dengan menggunakan eviews versi 5 .

\section{Kerangka Operasional}

Di dalam model eviews akan diduga hubungan antara peningkatan kualitas pendidikan dalam hal ini adalah lamanya sekolah (year of schooling), jumlah tenaga kerja dan investasi terhadap pertumbuhan ekonomi domestik (PDB) dari 33 propinsi di Indonesia. Berdasarkan tinjauan kepustakaan dan tujuan dari penelitian ini dapat dibangun kerangka pikir konseptual yang menggambarkan alur hubungan antara variabel bebas yaitu: lamanya sekolah, jumlah tenaga kerja, nilai investasi dan sumber daya alam pertambangan. Hubungan antara variabel bebas terhadap pertumbuhan ekonomi (PDB) adalah:

\section{Lamanya Kelulusan Sekolah}

Bila semakin lama bersekolah maka akan meningkatkan kualitas sumber daya manusia dimana peningkatan kualiatas sumber daya manusia akan meningkatkan produktifitas yang ditunjukkan dengan peningkatan pendapatan tenaga kerja dan sekaligus akan memberikan dampak terhadap pertumbuhan ekonomi.

\section{Jumlah Tenaga Kerja}

Jumlah tenaga kerja dalam variabel ini adalah diukur sebagai jumlah orang yang dihitung yang memiliki pendidikan dalam populasi aktif secara ekonomi. Dengan definisi pengukuran individu yang bekerja mewakili usia 15 tahun ke atas yang bekerja untuk dibayar atau mencari laba. Semakin banyak tenaga kerja yang bekerja di beberapa sektor maka akan memberikan dampak terhadap pendapatan yang diperoleh oleh pemerintah dengan adanya pembayaran pajak oleh para tenaga kerja dan sekaligus hal ini akan meningkatkan pertumbuhan ekonomi

\section{Nilai Investasi (PMTDB)}

Nilai investasi yang semakin besar jumlahnya akan dapat memberikan pertumbuhan ekonomi di suatu daerah.

4. Sumber Daya Alam (Produk Tambang)

Sumber daya alam tambang yang besar akan memberikan kontribusi yang besar terhadap pertumbuhan ekonomi di suatu daerah.

Hubungan antara keempat variabel variabel bebas tersebut dapat digambarkan dengan diagram seperti berikut: 


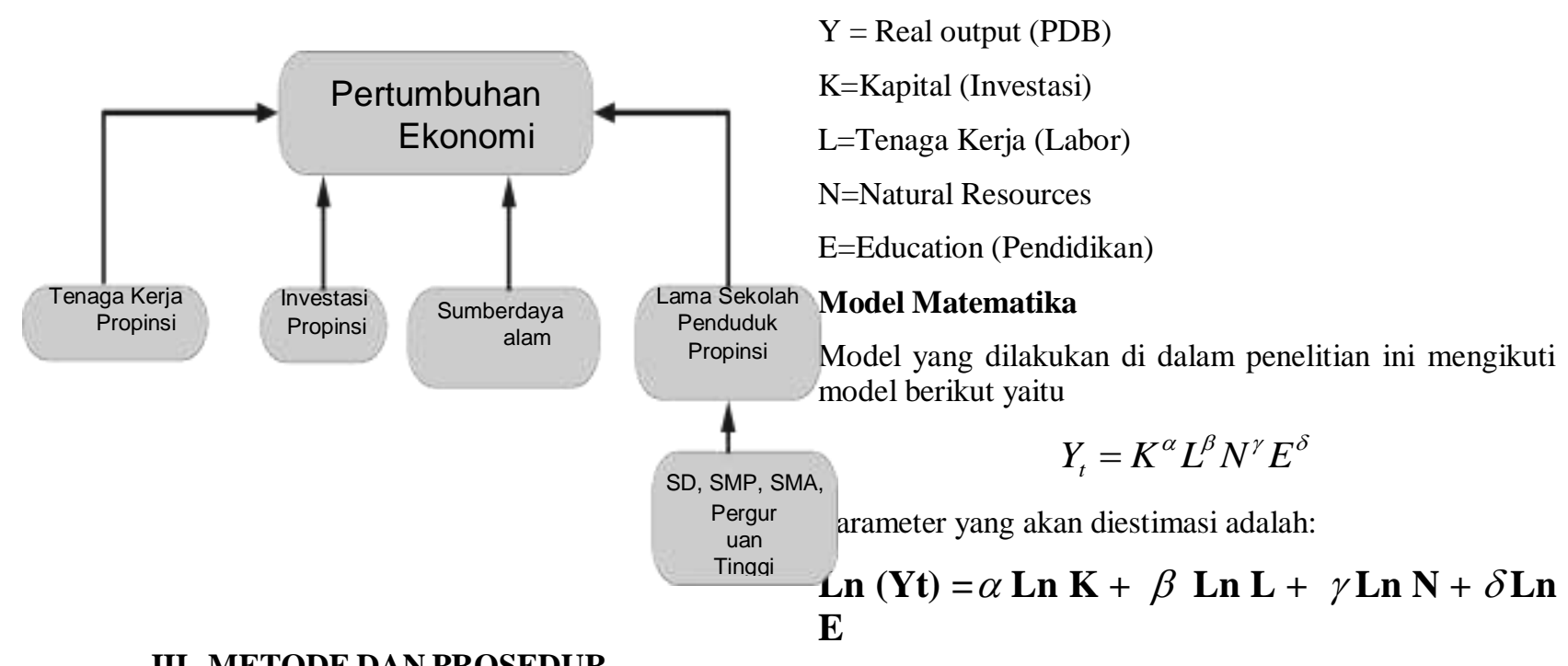

\section{Sample Data}

Data-data yang digunakan di dalam penelitian ini adalah data sebagai nilai- nilai dari variabel terikat yaitu: pertumbuhan ekonomi (PDB), sedangkan nilai variabelvariabel bebas meliputi lamanya sekolah (sekolah), jumlah tenaga kerja (labor), sumber daya alam (tambang) dan nilai investasi (investasi). Data tersebut merupakan data panel pada tahun 2003-2005. Data-data yang digunakan diperoleh dari data SUSENAS yang dikeluarkan oleh Badan Pusat Statistik (BPS).

\section{Pengumpulan Data}

Pengumpulan data dilakukan atas dasar pencarian, pemilihan, dan pencatatan serta katagori berdasarkan variabel terikat dan variabel bebas dari dokumen statistik yang dikeluarkan oleh Badan Pusat Statistik (BPS).

\section{Asumsi dan Penggunaan Variabel}

Pada penelitian ini variabel-variabel yang digunakan terdiri dari 1 variabel terikat dan 3 variabel bebas. Pertumbuhan ekonomi (PDB) sebagai variabel tak bebasnya, sedangkan variabel bebasnya meliputi lamanya sekolah (Sekolah), jumlah jumlah tenaga kerja (Labor), sumber daya alam (Produk Tambang) dan nilai investasi (PMTDB). Asumsi lainnya yang digunakan di dalam penelitian ini adalah asumsi statistik yang mendasari model regreasi linier, yaitu normalitas dan varian yang konstan dari variabel pengganggu. Beberapa uji akan dilakukan terhadap parameter dengan menggunakan asumsi-asumsi tersebut.

\section{Model dan Metode Analisis}

Model yang diusulkan di dalam penelitian ini adalah model linier variabel berganda untuk mengakomodasi ketiga faktor yang diduga mempengaruhi pertumbuhan ekonomi (PDB). Hubungan ketiga variabel bebas terhadap variabel tak bebas tercermin di dalam bentuk fungsi sebagai berikut

$$
\mathrm{Yt}=f(K, L, N, E)
$$

Untuk mendapatkan model ekonometri dari model matematikanya maka beberapa variabel seperti $\mathrm{K}, \mathrm{N}, \mathrm{L}$, dan E selanjutnya secara berturut-turut akan menggunakan variabel yaitu: pmtdb, produk tambang, jumlah tenaga kerja (labor), dan lamanya sekolah. Hal tersebut dapat dilihat seperti tabel di bawah ini:

\begin{tabular}{|c|c|}
\hline $\begin{array}{c}\text { Variabel Model } \\
\text { Matematika }\end{array}$ & $\begin{array}{c}\text { Variabel Model } \\
\text { Ekonometrika }\end{array}$ \\
\hline $\mathrm{K}$ & PMTDB \\
\hline $\mathrm{N}$ & Produk Tambang \\
\hline $\mathrm{L}$ & Jumlah Tenaga Kerja \\
\hline $\mathrm{E}$ & Lamanya Sekolah \\
\hline
\end{tabular}

Selanjutnya akan dibuat model ekonometri sebagai model di dalam penelitian ini. Model tersebut dapat digambarkan di dalam persamaan seperti di bawah ini

$$
\operatorname{Ln} Y_{i t}=\beta_{0}+\beta_{1} \operatorname{Ln} X_{1 i t}+\beta_{2} \operatorname{Ln} X_{2 i t}+\beta_{3} \operatorname{Ln} X_{3 i t}+\beta_{4} \operatorname{Ln} X_{4 i t}+e_{i t}
$$

$Y_{t}=$ nilai $\mathrm{PDB}, \beta_{0}=$ intersep

$\beta_{1}, \beta_{2}, \beta_{3}, \beta_{4}, \beta_{5=}$ parameter masing-masing variabel yang akan diuji secara statistik dan ekonometri.

$i=$ propinsi

$X_{1}=$ lamanya sekolah (year of schooling)

$X_{2}=$ jumlah tenaga kerja (labor)

$X_{3}=$ nilai produk tambang 
$X_{4}=$ nilai pembentukan modal tetap domestik bruto (PMTDB)

\section{PENGUJIAN MODEL}

\section{K sebagai pmtdb}

Variabel K menggunakan PMTDB (pembentukan modal tetap domestik bruto) sebagai proksi, karena keterbatasan untuk mencari data mengenai kapital stok maka digunakan proksinya investasi yaitu PMTDB. Hal ini disebabkan karena PMTDB merupakan data tentang perubahan kapital stok $(\Delta K)$.

\section{N sebagai produk tambang}

Variabel N menggunakan produk tambang sebagai proksi, karena sumber daya alam yang paling mewakili untuk natural resources adalah produk tambang. Beberapa sumber daya alam yang lainnya misalnya pertanian, perikanan dan yang lainnya dapat juga digunakan namun sumber daya alam. Hal ini dikarenakan produk tambang yang paling mewakili khususnya di dalam penggunaan sumber daya alam tambang. Sumber daya alam adalah nilai dari tanah pertanian di tiap negara, hutan, lapisanlapisan antara tanah dan batuan termasuk logam, mineral, batubara, minyak, dan gas alam (Weil, 2009). Sumber daya alam dan PDB per kapita memiliki hubungan yang positif yaitu negara-negara yang memiliki sumber daya alam yang lebih cenderung untuk mendapatkan pendapatan yang lebih tinggi. Namun ada pengecualian bahwa sumber daya alam yang melimpah membuat negara menjadi kaya. Misalnya Belgia, Jepang, dan Switzerland adalah negara-negara yang kurang memiliki sumber daya alam yang lebih namun mereka juga memiliki pendapatan per kapita yang tinggi. Hal yang sama juga terjadi untuk Nigeria, Venezuela, dan Ekuador adalah negara-negara yang memiliki sumber daya alam yang tingi namun pendapatan per kapitanya rendah.

\section{L sebagai jumlah tenaga kerja}

Variabel L menggunakan jumlah tenaga kerja, karena jumlah tenaga kerja merupakan jumlah penduduk yang bekerja. Penduduk yang tidak bekerja tidak dimasukkan ke dalam variabel jumlah tenaga kerja di dalam model tersebut.

\section{E sebagai waktu lamanya kelulusan (year of schooling)}

Variabel E menggunakan lamanya sekolah, karena waktu lamanya sekolah merupakan variabel yang mewakili untuk tingkat pendidikan seseorang. Estimasi model yang telah kita buat di atas selanjutnya akan dilakukan uji spesifikasi model dan diagnosis (modelling) terlebih dahulu. Hal ini untuk membuktikan apakah model yang kita bangun sudah tepat atau tidak bias lagi ${ }^{20}$. Apabila model yang kita bangun sudah tepat maka kita bisa membuat generalisasi melalui uji statistik. Kemudian dari hasil estimasi dapat dilakukan prediksi atau peramalan. Apabila model belum tepat maka kita meninjau kembali spesifikasi model yang kita bangun.
KOEFISIEN DETERMINASI $\left(R^{2}\right)$ (GUJARATI, $2003: 81-87$ ) Merupakan suatu bilangan yang dinyatakan dalam bentuk persen, yang menunjukkan besarnya pengaruh variabel independen terhadap variabel dependen.

Koefisien determinasi $R^{2}$ digunakan untuk mengukur kebenaran hubungan dari model yang dipakai yaitu angka yang menunjukkan besarnya kemampuan varians/ penyebaran dari variabel independen yang menerangkan variabel dependen. Besarnya nilai $R^{2}$ berada diantara $0<R^{2}<1$ apabila nilai semakin mendekati 1 berarti model tersebut bisa dikatakan baik karena semakin mendekat hubungan antar variabel independen dengan variabel dependen, dan sebaliknya.

\section{Uji t-statistik (Gujarati, 2003 : 129 - 133)}

Uji yang digunakan untuk mengetahui suatu variabel independen benar-benar signifikan secara statistik mempengaruhi variabel dependen, maka dilakukan uji parsial dengan menggunakan uji t-statistik. Uji t-statistik ini dilakukan dengan dua arah dimana hipotesis yang digunakan adalah:

1. H1o $\beta_{1}=0$ (lamanya waktu sekolah tidak mempengaruhi PDB)

$\mathrm{H} 1_{\mathrm{A}}: \beta_{1} \neq 0$ (lamanya waktu sekolah mempengaruhi PDB)

2. $\mathrm{H} 2 \mathrm{o} \beta_{2}=0$ (jumlah tenaga kerja tidak mempengaruhi PDB)

$\mathrm{H} 2_{\mathrm{A}}: \beta_{2} \neq 0$ (jumlah tenaga kerja mempengaruhi PDB)

3. $\mathrm{H} 3 \mathrm{o}: \beta_{3}=0$ (nilai investasi tidak mempengaruhi PDB)

$\mathrm{H} 3_{\mathrm{A}}: \beta_{3}=0$ (nilai investasi mempengaruhi PDB)

Atau dapat diringkaskan menjadi $\mathrm{Ho}: \beta_{1}=0, \beta_{2}=0, \beta_{3}=$ 0 , dan $\mathrm{H} 1: \beta_{1} \neq 0, \beta_{2} \neq 0$,

$\beta_{3} \neq 0$. Analisisnya, jika nilai statistik lebih besar dari nilai kritis table pada tingkat signifikansi 5\% maka kita menolak hipotesis nol dan menerima hipotesis alternative artinya lamanya waktu sekolah, jumlah tenaga kerja dan nilai investasi mempengaruhi pertumbuhan ekonomi (PDB).

\section{Uji f-statistik (Gujarati, 2003 : 129 - 133)}

Uji yang dilakukan untuk mengetahui apakah keseluruhan variabel independen mempengaruhi variabel dependen secara signifikan, maka dilakukan uji keseluruhan atau uji F-statistik. Hipotesis yang digunakan untuk uji F-statistik ini adalah 
1. Ho : $\beta_{1}=\beta_{1}=\beta_{2}=\beta_{3}=0$ (lamanya sekolah, jumlah tenaga kerja, dan nilai investasi secara bersamasama tidak mempengaruhi pertumbuhan ekonomi)

2. $\mathrm{H}_{\mathrm{A}}: \beta_{1}=\beta_{1}=\beta_{2}=\beta_{3} \neq 0$ (ditemukan setidaknya ada satu variabel bebas yang mempengaruhi variabel tidak bebas secara signifikan)

Dengan degree of freedom:

df untuk pembilang, $\mathrm{N}_{1}=\mathrm{k}-1, \mathrm{k}$ adalah banyaknya parameter.

df untuk penyebut, $\mathrm{N}_{2}=\mathrm{n}-\mathrm{k}, \mathrm{n}$ adalah banyaknya observasi.

Maka kriteria yang digunakan adalah:

Ho: ditolak apabila F-stat > F-tabel

Ho: tidak ditolak apabila F-stat $\leq$ F-tabel.

\section{Uji Multikolinearitas}

Uji ini dilakukan untuk mengetahui suatu kondisi dimana tidak terdapat hubungan yang linier sempurna di antara beberapa atau semua variabel independen dalam sebuah model regresi $(C L R M=$ Classical Linier Regression Model).

Multikolinearitas dapat diartikan sebagai hubungan linier diantara beberapa atau semua variabel independen dalam sebuah model regresi. Hubungan antara variabel independen yang satu dengan variabel independen lainnya adalah dapat dideteksi dengan melakukan regresi atas satu variabel independen terhadap variabel independen lainnya kemudian dihitung $R^{2}$ nya. Apabila nilai $R^{2}$ hasil regresi tersebut lebih kecil dari nilai $R^{2}$ nya hasil regresi output terhadap variabel input secara keseluruhan, maka secara keseluruhan tidak terjadi multikolinearitas dari model tersebut.
$\operatorname{Ln} Y_{i t}=\beta_{0}+\beta_{1} \operatorname{Ln} X_{1 i t}+\beta_{2} \operatorname{Ln} X_{2 i t}+\beta_{3} \operatorname{Ln} X_{3 i t}+\beta$ ${ }_{4} \operatorname{LnX}{ }_{4 i t}+e_{i t}$

Dimana

$Y_{t}=$ nilai $\mathrm{PDB}$;

$\beta_{0}=$ intersep

$\beta_{1}, \beta_{2}, \beta_{3}, \beta_{4}, \beta_{5=}$ parameter masing-masing variabel yang akan diuji secara statistik, dan ekonometri $i=$ propinsi.

$\mathrm{t}=$ waktu (tahun)

$X_{1}$ = lamanya sekolah (year of schooling)

$X_{2}=$ jumlah tenaga kerja (labor)

$X_{3}=$ nilai produk tambang

$X_{4}=$ nilai pembentukan modal tetap domestik bruto (PMTDB)

Dengan menggunakan metode OLS maka persamaan yang akan diperoleh adalah:

$\operatorname{Ln}($ GDP $)=\beta_{0}+\beta_{1} \operatorname{Ln}($ YOS $)+\beta_{2} \operatorname{Ln}($ Labor $)+\beta_{3}$ Ln(Produk tambang $)+\beta_{4}$ pmtdb $+e_{t}$

Dimana :

$\ln$ GDP

: logaritma natural dari

PDB

In YOS

year of schooling (YOS)

In Labor
: logaritma natural dari

: logaritma natural dari jumlah ten

\section{Uji Autokorelasi}

Hasil pengujian t-statistik

Autokorelasi terjadi karena adanya hubungan antara error terms. Masalah autokorelasi terjadi diakibatkan hal hal seperti : bentuk fungsi persamaan yang salah, manipulasi data, dan adanya variabel lags. Akibatnya akan terjadi masalah autokorelasi yaitu persamaan regresi menjadi tidak efisien.

Pengujian yang dilakukan adalah melalui uji DurbinWatson d test dan apabila diperlukan digunakan Run Test. Selain dari kedua metode tersebut masih ada uji autokorelasi lainnya yaitu : Breusch dan Godfrey yang dikenal dengan Lagrange Multiplier Test.

Berdasarkan hasil pengolahan pengujian data di atas,

\begin{tabular}{|c|c|c|l|}
\hline Variabel & t-statistik & Ho & Keterangan \\
\hline Intercept & 10.69254 & Ditolak & $\begin{array}{l}\text { Signifikan } \\
\alpha=0.05\end{array}$ \\
\hline Ln YOS & 4.458371 & Ditolak & $\begin{array}{l}\text { Signifikan } \\
\alpha=0.05\end{array}$ \\
\hline Ln Labor & 2.182716 & Ditolak & $\begin{array}{c}\text { Signifikan } \\
\alpha=0.05\end{array}$ \\
\hline Ln Tambang & 5.781195 & Ditolak & $\begin{array}{l}\text { Signifikan } \\
\alpha=0.05\end{array}$ \\
\hline PMTDB & 5.358133 & Ditolak & $\begin{array}{c}\text { Signifikan } \\
\alpha=0.05\end{array}$ \\
\hline
\end{tabular}
maka persamaan regresi ganda dapat dimodelkan sebagai berikut: 


\section{KESIMPULAN DAN SARAN}

Pada bagian ini akan diperoleh kesimpulan dari hasil penelitian yang dilakukan oleh variabel-variabel bebas seperti year of schooling (YOS), jumlah tenaga kerja, share pertambangan, dan nilai investasi terhadap pertumbuhan ekonomi di masing-masing propinsi.

\section{Kesimpulan}

Berdasarkan hasil perhitungan dan observasi mulai dari tahun 2003 hingga 2005, serta pembahasan di bagian sebelumnya, maka dapat ditarik kesimpulan sebagai berikut:

1. Tingkat kelulusan pendidikan (year of schooling) mempunyai pengaruh yang cukup besar terhadap nilai pertumbuhan ekonomi propinsi (PDB). Hal ini memang terlihat dari koefisien yang positif dimana memberikan arti bahwa tingkat pendidikan juga memberikan kontribusi yang signifikan terhadap pertumbuhan ekonomi.

2. Semakin lama waktu sekolah yang dibutuhkan memberikan arti bahwa setiap orang yang mempunyai pendidikan akan memiliki kemampuan untuk mencukupi kebutuhannya sendiri, dan kemampuan untuk memperoleh kesempatan bekerja.

3. Industri pertambangan memberikan kontribusi yang besar terhadap perekonomian daerah maupun nasional. Dampak ekonomi yang ditimbulkan antara lain memberikan pertumbuhan ekonomi yang cukup baik.

\section{Saran}

1. Perlu diciptakan iklim investasi yang menguntungkan bagi pemerintah, masyarakat dan penanam modal. Hal ini dikarenakan peran investor asing masih sangat besar.

2. Disarankan untuk lebih baik memperoleh kesempatan untuk mendapatkan pendidikan, karena hal tersebut merupakan investasi yang nantinya akan berguna di jangka panjang

\section{DAFTAR PUSTAKA}

Badan Pusat Statistik. (2006). PDRB Propinsi-propinsi di Indonesia menurut Lapangan Usaha.

Badan Pusat Statistik. (1995). Statistik Indonesia. Edisi Tahunan.

Barro, Robert, and Jong-Wha Lee. (2000, September). “ International Data on Educational Attainment Updates and Implications.” NBER Working Paper 7911

Blanchard, Oliver.(2000). Macroeconomics, $2^{\text {nd }}$ edition, Prentice Hall. oleh Julius A. Mulyadi, Makroekonomi), Penerbit Erlangga, Jakarta.

Dornbusch, Rudiger, \& Stanley Fischer. (1990). Macroeconomics (Diterjemahkan oleh Julius A. Mulyadi, Makroekonomi), Penerbit Erlangga, Jakarta.
David N. Weil. (2009). Economic Growth, Second Edition, Pearson International Edition.

Gardner Auckley. (1961). Teori Ekonomi Makro, UIPress, Jakarta.

George Psacharopoulos, Maureen Woodhall. (1985). Education for Development, An Analysis of Investment Choices.

Gordon, Robert J. (1978). Macroeconomics. Little Brown and Company, Boston.Toronto.

Green, William H. (2000). Econometric Analysis, Fourth Edition, New Jersey.

Hall, Robert, and Charles Jones. (1999). "Why Do Some Countries Produce So Much More Output per Worker than Others?" Quarterly Journal of Economics 114 (February): 83-116.

Khorasgani, Mahdi Fadaee., Payam Noor University, Isfahan, Iran. (2008). Higher Education Development and Economic Growth in Iran. Journal of Education, Business and Society, 162-173.

Krugman Paul R \& Obstfeld Maurice. (2003). Ekonomi Internasional, Teori dan Kebijakan, Edisi Kedua, PAUFE UI dan HarperCollins Publishers, PT RajaGrafindo Persada.

Lauder, Hugh, Education, Democracy and the Economy, British Journal of Sociology of Education pp.417-431, Taylor and Francis.

Mahdi Fadaee Khorasgani, Payam Noor University, Isfahan, Iran, Higher education development and economic growth in Iran.

Mankiw, N. Gregory. (2003). Teori Makroekonomi, Edisi Kelima, Erlangga Jakarta,

Nachrowi, Nachrowi D. dan Usman, Hardius. (2006). Pendekatan Populer dan Praktis Ekonometrika untuk Analisis Ekonomi dan Keuangan. Lembaga Penerbit Fakultas Ekonomi Universitas Indonesia.

Ndiyo, Ndem Ayara, A Dynamic Analysis of Education and Economic Growth in Nigeria.

Rahardja, Prathama dan Mandala Manurung. (2001). "Teori Ekonomi Makro". LP- FEUI.

Ray, Debraj. (1998). Development Economics, Princeton University Press, New Jersey.

Romer, David. (1996). Advance Macroeconomics.Singapore, The Mc. Graw-Hill Companies, Inc.

Samuelson, Paul A. (1996). Makroekonomi, (Edisi XIV), Penerbit Erlangga.

Todaro, Michael. P. (2000). Economics Development, Seventh Edition, Person Eduction Limited.

Widarjono, Agus. (2007). Ekonometrika: Teori dan Aplikasi untuk Ekonomi dan Bisnis. Ekonosia, Kampus Fakultas Ekonomi UII.

V. A. Zhamin \& S. L. Kostanian, International Review of Education pp.155-171, Springer. 